\title{
Arricles
}

\section{ECJ bans Discrimination against Non-residents}

Prof. Dr. Brigitte Knobbe-Keuk*, Holder of a chair in commercial, economic and tax law, director of the Tax Law Institute, University of Bonn

\section{Introduction}

The tax laws of European Union Member States must no longer discriminate against non-nationals who live in one Member State and commute to work in another. This is the message of the ECJ ruling of 14 March 1995 in the Schumacker case. ${ }^{1}$

It was not the first time the Court was confronted with a case of a non-resident taxpayer following his profession across the borders and being discriminated against by the taxing host State. But the judgment in the previous similar Werner case ${ }^{2}$ was most disappointing for the taxpayers concerned. However it was by no means a landmark ruling on the issue of discrimination against non-resident taxpayers and its compatibility with EC law. The Werner case was not the right case for the Court ${ }^{3}$ because the non-resident Mr. Werner who had been discriminated against by the German tax law was a German national neither having performed a business or a professional activity in a Member State other than that of origin nor having acquired a vocational qualification elsewhere. The Court simply held that a Member State is not prevented by the Treaty from discriminating against its own nationals. The only element going beyond a purely national setting, i.e. the residence in another Member State, was considered to be insufficient for applying Article 52 of the Treaty. This reasoning did not work in the Schumacker case. In this case the Court was to nail its colours to the mast and did so.

\section{The Facts and the Procedure}

Mr. Schumacker, a Belgian national, had in 1988 and 1989, the years at issue, his sole permanent residence and his usual abode in Belgium and was married there. His wife did not work, but drew unemployment benefit in Belgium. Initially Mr. Schumacker worked in Belgium for his German employer. From 15 March 1988 to 31 December 1989 he worked in Cologne (Germany) for the same employer.

Since then Germany had the right to tax his professional income in accordance with Article 15 para. 1 of the Belgium/Germany Double Tax Treaty. Accordingly wage tax was deducted from his wages in Germany. However Mr. Schumacker was taxed at rates applicable to single individuals and to non-residents regardless of their family circumstances. Particularly he was not granted the split-rate benefit.

The German splitting arrangement is based on a conception of marriage which treats spouses as a unit as regards their ability to pay. Their income is not allocated separately to the spouse who has acquired it by means of his gainful activity. Instead the couple's income is taxed as if each of them had earned half of it.

Under Paragraph 26 para. 1 of the German Einkommensteuergesetz however a condition of allowing the splitting system is that both spouses are resident in Germany and subject to unlimited tax liability.

\footnotetext{
* The author was involved in the Schumacker procedure. She advised the Commission of the European Communities.

${ }^{1}$ ECJ of 14 February 1995 Case C-279/93.

2 ECJ of 26 January 1993 Case C-112/91 (Werner).

${ }^{3}$ See the annotation by Knobbe-Keuk, Common Market Law Review 1993, 1
} 
Mr. Schumacker claimed that he should be entitled to be taxed by reference to the split-rate applicable to married residents. The refusal by the German tax authorities, based on Paragraph 26 of the Einkommensteuergesetz, to grant Mr. Schumacker the same tax treatment as his colleagues residing in Germany results in a tax charge which is roughly 8,000 DM higher than that of his colleagues residing in Germany.

By judgment of 14 April $1993^{4}$ the German Supreme Fiscal Court (Bundesfinanzhof) referred to the ECJ for a preliminary ruling relating to the interpretation of Article $48 \mathrm{EC}$ Treaty (free movement of workers). The referring German Court wanted to learn what bearing Article 48 of the Treaty had on German tax law.

No less than six Member States were represented at the ECJ's hearing of 18 October 1994 to defend their tax systems and to advocate the compatibility of discrimination against non-resident taxpayers with EC law. Once more they fought in concert with tooth and claw as they had done in the Werner case - to repulse what they may conceive to be an attack on their tax sovereignty.

However, the subject of the case was not even so exceptional and outrageous as one could believe in regard to the observations of the Member States. All essential mosaic elements of the subject matter of litigation at issue had been decided by the Court long ago. It was only still necessary to bring in line the exercise of the jealously guarded right of the Member States to dictate income laws with the individual right of EC nationals to work in another Member State without discrimination, and to draw the consequences for the concrete case.

\section{The Judgment}

Therefore the ruling, in substance, does not bring any surprising news which develop further Community law.

a. At first the German Court put, curiously enough the amazing question whether Article 48 of the Treaty could restrict the right of a Member State to subject a national of another Member State to income taxation. Given the fact that the fathers of the Treaty had treated the field of direct taxation as a poor cousin and that the Treaty contrary to the area of indirect taxation contained neither a specific basis for harmonisation nor a specific ban of discrimination the referring German Court observed a fundamental need for clarifying the question whether the levying of income tax by EC Member States is subject to the restrictions of Article 48 et seq. of the EC Treaty at all.

It did not come as a surprise that the European Court of Justice reaffirmed once more what it had ruled enough times over the last years: the fundamental rights enshrined in the Treaty preclude all discriminatory national provisions in all areas without exception. ${ }^{5}$ Also national tax provisions must not escape Community law. It is of course quite clearly for the Member States to dictate the rulings governing income tax. Nevertheless, the Member States must respect the limits laid down by Community law.

It goes without saying that regarding Community law things are quite different from the DTC situation. In international double taxation law the interests of the contracting States are to the fore and the standing of the individual taxpayer is most poor. Private persons are neither given rights nor remedies by the DTCs. In contrast, under Community law private persons have a strong standing. They enjoy the rights conferred by the Treaty. Accordingly under Community law the non-discrimination problem is really a legal and not a political one.

But the referring Court would not be convinced by the rulings of the ECJ: ${ }^{6}$

'The judgments do not, however, contain any convincing statement of reasons why Article 48 et seq. of the EC Treaty should relate to tax.'

But the reason had been already made very clear in the Biehl ruling: ${ }^{7}$

'The principle of equal treatment with regard to remuneration would be rendered

\footnotetext{
${ }^{4}$ Bundesfinanzhof of 14 April 1993 Bundessteuerblatt II 1994, 27.

${ }^{5}$ Case Schumacker point 21.

${ }_{7}$ See the Bundesfinanzhof-ruling requesting the preliminary ruling (supra footnote 4).

ECJ Case C-175/88 (Biehl) 1991 ECR I, 1779.
} 
ineffective if it could be undermined by discriminatory national provisions on income tax.'

This statement has been reiterated by the Court in the Schumacker ruling.

b. The heart of the problem of the requesting Court lies in its second and third question. These questions are not quite simply worded and the European Court responded to them together. In substance the German Court wanted to learn: Does Article 48 of the Treaty preclude the Federal Republic of Germany from taxing a Belgian national residing in Belgium and having acquired his vocational qualification and professional training in Belgium at a higher rate than that to which a person residing in Germany is subjected under the same circumstances, particularly in the case that the Belgian national is drawing his income exclusively or nearly exclusively from German sources?

Given the fact that most States prefer the criterion of residence to the criterion of nationality for determining the jurisdictional basis of their income tax system, national tax provisions do expressly not treat persons differently on grounds of nationality as a rule. Therefore the German government and other governments argued that there was no discrimination on grounds of nationality - as in Article 48 and Article 52 of the Treaty required. Against this background the ECJ was to reaffirm its established case law relating to covert discrimination once more: The principle of equal treatment, of which Articles 48 and 52 embody specific instances, prohibits not only overt discrimination by reason of nationality but also all covert forms of discrimination which, by the application of other criteria of differentiation, lead in fact to the same result. ${ }^{8}$ The Court assumes covert discrimination if the provision at issue using the criterion of residence works in particular against nationals of other Member States, ${ }^{, 9}$ or works 'more particularly to the disadvantage of companies having their seat in other Member States'. ${ }^{10}$

The crucial test is whether, in fact, a resident and a non-resident are in comparable fiscal circumstances. Only then (covert) discrimination would be possible.

In principle residents are fully liable to tax in the State of residence, usually on their world-wide income ('unlimited tax liability'), whereas non-residents generally are subject to tax only in respect of income deriving from sources in the State concerned. Usually personal tax allowances (e.g. deductions or abatements in respect to spouse, children, age and other personal circumstances) or any other form of tax relief are available only for residents. This accords with the principle that such persons be taxed (with their worldwide income) according to their ability to pay. In the case of non-residents usually the situation is another one. The connections with the source State are limited only to the economic activities carried on there. The residence State has the right to tax the other income items. Therefore granting personal tax allowances is regarded as a matter of this State.

The rationale behind this treatment is that otherwise taxpayers engaging in cross-border activities would get the personal deductions twice, first in the source State and second in the residence State. Insofar the tax treatment of non-residents is plausible and conclusive. But this solution is stumped in the case that the 'worldwide' respective nearly the 'worldwide' income of a taxpayer residing in State A is identical with the income derived from the activity in State B. Because the State of residence is prevented from taxing the foreign sourced income by the double tax Treaty it has not the opportunity to grant personal allowances in computing income tax. The taxpayer is caught in a trap. His ability to pay is diminished because of his family responsibilities and other circumstances which affect his economic disposing power. But neither the State of residence nor the taxing source State take into account the reduction in his taxable capacity.

And this is the point where the non-resident and the resident are placed in comparable situations: The resident is liable to tax with his worldwide income; the same is true, in fact, for the non-resident. Because the non-resident does not get any family and personal tax allowances in the State of residence he is - compared with a resident - discriminated against if the taxing State of activity refuses to grant him the same tax treatment as it grants to residents.

However the different treatment depending on the residence might, under certain conditions, be justified in an area such as tax law. Since that statement of the avoir fiscal ruling $^{11}$, i.e. the landmark ruling concerning discriminatory provisions in the field of direct

\footnotetext{
${ }^{8}$ See ECJ Case 152/73 (Sotgiu) 1974 ECR, 153, point 11; ECJ Case Biehl (supra footnote 7); Case C 330/91 (Commerzbank).

${ }_{9}$ ECJ Case Biehl (supra footnote 7).

${ }^{10}$ ECJ Case Commerzbank (supra footnote 8).

${ }^{11}$ ECJ Case 270/83 (Avoir Fiscal) 1986 ECR 401 point 21
} 
taxation the Court has discussed potential justifications of the different treatment in all direct taxation cases it was engaged in. It is noteworthy that the Court has not restricted the considered justification reasons to those listed in Article 48 para. 3 respective Article 56 of the Treaty. The Court did never explain its specific approach applying the non-specific fiscal provisions of the Treaty in the area of direct taxation. In our opinion two reasons emerge above all, neither new but worth stressing.

At first: The heart of the problem of discriminatory tax provisions does not lie in discrimination on grounds of nationality. But it goes without saying that not any differentiation between resident and non-resident taxpayers constitutes a (covert) discrimination on grounds of nationality. Second: In direct taxation cases two conflicting principles collide. On the one hand direct taxation has been left to the sovereignty of the Member States; it is quite clearly for the Member States alone to write their tax laws. On the other hand the EU citizens are granted the fundamental right to free movement and establishment by the Treaty - without discrimination. For complying these conflicting principles it is necessary to weigh up them. But weighing up requires at first the clarification on whether there exists a general public interest of the taxing State in distinguishing between residents and non-residents. Only then it is possible to decide if priority is to give the general public interest or the individual rights enshrined in the Treaty.

Against the background of these considerations it is not especially surprising that the Court discusses the justification of discriminatory tax provisions. In the Schumacker case the Court dealt with two justification arguments. At first the Court considered the much discussed brainchild of the Bachmann case ${ }^{12}$, i.e. the 'coherence of the national tax system'. In their observations the Member States had relied upon that arcane and elusive principle ${ }^{13}$ and had argued that there is a link between the right to tax the worldwide income and taking into account the familiar and personal situation of the taxpayer. But the Court made short drift. It did not appreciate that argument in a case in which the State of residence having the right to tax the worldwide income could not make the necessary familiar and personal deductions due to a lack of taxable income in the residence State.

The second argument advanced by the German tax authorities for justifying the discrimination was that there would be administrative difficulties for the State of activity to check the familiar and personal circumstances and the income drawn from sources in the residence State or from sources in a third State and that without making a check on that it would not be possible to assess correctly the income tax payable. This argument the Court rejected noting Council Directive 77/799/EEC of 19 December 1977 concerning mutual assistance by the competent authorities of the Member States in the field of direct taxation. ${ }^{14}$ Also in this respect the position of the Court is not a new one. ${ }^{15}$ Furthermore The Court has repeatedly stressed in its decisions that considerations of an administrative nature cannot justify derogation by a Member State from the rules of community law. That principle is told to be applied with even greater force where the derogation in question amounts to preventing the exercise of one of the fundamental freedoms guaranteed by the Treaty. ${ }^{16}$

After having dismayed these two justification arguments the Court pointed out that according to a bilateral tax treaty between Germany and the Netherlands workers who have their fiscal residence in one of the contracting States while drawing nearly their worldwide income in the other State, these taxpayers are subject to the same tax treatment (including the application of the split rate) as resident taxpayers (para. 46). The meaning of this statement is not quite clear. It is unlikely that the Court intended to rule that the nationals of one Member State must not be discriminated against compared with the nationals of another Member State, and that they can rely on a bilateral Treaty concluded between two other Member States. We believe that also the Court is of the opinion that the different treatment of non-residents who are entitled to rely on a bilateral agreement between the State of activity and their State of origin, and those non-residents who are not entitled is justified. ${ }^{17}$ At first, in fact, Article 48 and Article 52 EC Treaty require that nationals of other Member States are treated in the host State in the same way as nationals of that State. ${ }^{18}$ Therefore it is

\footnotetext{
12 ECJ Case C 204/90 (Bachmann) 1992 I ECR, 249.

${ }^{13}$ See more detailed Knobbe-Keuk Restrictions on the Fundamental Freedoms Enshrined in the EC Treaty by Discriminatory Tax Provisions - Ban and Justification - EC Tax Review 1994, 74 et seq.

${ }^{14}$ O.J. 1977 L 336 p. 15.

15 See also ECJ Case 204/90 (Bachmann) 1992 I ECR, 249 para. 18 et seq.

${ }^{16}$ ECJ Case 29/82 (Van Luipen) 1983 ECR 151; ECJ Case 205/84 (Commission v. Germany) 1986 ECR 2793.

17 In respect of this problem, see more detailed Knobbe-Keuk, Europäische Zeitschrift für Wirtschaftsrecht $1991 \mathrm{p}$ 653.

${ }^{18}$ However the requirement for equal treatment is only the most important case of a more far-reaching general ban on restrictions. See more detailed Knobbe-Keuk, Der Betrieb 1990, 2573.
} 
to be assumed that the Court by pointing out the taxable situation of Dutch workers in Germany only intended to confirm that equal treatment is feasible and that neither the 'concept' of 'coherence' nor administrative difficulties were to be objected.

c. Considering the fourth question the Court ruled that it was contrary to Article 48 to exclude individuals who have no permanent residence or usual abode in Germany but derive income from employment there from the annual wages tax adjustment and also to deny them from the possibility of being assessed for income tax with account being taken of earnings from employment. That part of the ruling is simply the continuation of the Biehl ruling.

\section{The Implications of the Ruling on German Tax Law}

Although the ruling does not contain any news in respect to Community law the implications on the national income tax systems are most weighty. This is true especially for the German income tax law.

a. During the Schumacker procedure Germany had started in August 1993 legislative proceedings to adapt its domestic law applying to non-resident taxpayers in order to ameliorate the tax situation of this taxpayers group. In June 1994 the new Frontier Workers Act was adopted. Indeed, a series of discriminations have been abolished by this act. The new act applies to non-resident taxpayers - provided that their 'worldwide' income or nearly ${ }^{19}$ their 'worldwide' income ${ }^{20}$ has been drawn from German sources. But just those two discriminations the Court had to deal with in the Schumacker case were not settled. The application of the splitting rate for spouses remains denied as well as an annual wages tax adjustment resp. an annual income tax adjustment.

b. Over the past years the German government again and again has strongly opposed requests, in particular those of the Commission to apply the split rate system also to frontier workers. In the new 'Grenzpendlergesetz' Germany has uphold this stance. It is in this point that the new German act essentially deviates from the Recommendation based on Article 189 EC Treaty issued by the Commission in December $19933^{21}$

Furthermore, in Germany it is a popular fallacy that German constitutional law forbids to distinguish between foreigners who are nationals respective residents of another Member State and nationals resp. residents of a third country. But treating all foreigners equal to residents in a comparable tax situation and granting all foreigners the split-rate benefit would be most expensive. On this ground Germany simply denies the split-rate benefit to all foreigners and violates in this way its obligations based on the EC Treaty. However it has to be stressed that making an exception for EU-citizens would be justified and would not contravene German constitutional law, because EU-citizens have in all Member States a special and extraordinary status compared to nationals of third countries.

The Schumacker ruling requires that Germany (and the other Member States concerned) eventually complies with its Community law obligations. If Germany does not want to make the whole of the world happy and if it intends to avoid unnecessary revenue losses and budgetary implications, it should restrict equal treatment of non-residents with that of residents in a comparable income situation on the EU-citizens. In principle, Germany should orientate towards the Recommendation issued by the Commission under Article 189 EC Treaty. ${ }^{22}$ It is beyond question that one may debate about details (e.g. is it necessary that 90 to 75 per cent of the non-resident's total income derive of the State of activity? should the host State be allowed to tax the income drawn of its territory with or without a proviso on progressive tax rates? etc.). But about the outline and direction of the necessary amendments Germany has to carry out, there is no argument.

c. Second: The Schumacker ruling compels Germany to remove eventually the exclusion of EC non-resident taxpayers from the annual wages tax adjustment resp. from an annual income tax adjustment. Already the Biehl ruling of the ECJ made it most clear that Article 48 EC Treaty requires equal treatment of resident and non-resident taxpayers under procedural rules, too, provided they are in a comparable situation. ${ }^{23}$

\footnotetext{
${ }^{19}$ In respect of the details see the overview of the draft by Kiblböck, EC Tax Review 1994, 66.

${ }^{20}$ I.e. at least 90 per cent. Foreign sourced income not exceeding 10 per cent of the worldwide income or up to DM 12.000 will not exclude the application of the new act.

${ }^{21}$ O.J. L 39 of 10 February 1994, p. 22. An overview gives Schonewille, EC Tax Review 1994, 63 et seq. See also the overview given by Thömmes/Kiblböck, European Taxation 1994, 202 et seq.

22 See footnote 21 .

${ }^{23}$ For establishing a 'comparable situation' a correct comparison is needed. It has to be compared the situation of the individual non-resident taxpayer with that of a resident taxpayer in respect to the national tax provision at issue. See further detailed Knobbe-Keuk, EC Tax Review 1994, 77 et seq.
} 
Regrettably the Biehl ruling did not induce Germany to amend its tax laws in order to comply with the fundamental freedoms guaranteed by the Treaty. But this behaviour is the usual and typical manifestation of German legislature. Even if it is quite clear that a tax provision contravenes German Constitutional or Community law Germany fancies itself in the role of martyr and is waiting for suffering a defeat at the Court concerned. Time is money. In the meantime Germany collects taxes which it is - as the Court concerned will decide sometimes - not entitled to.

d. Further it has to be emphasized that the discrimination problem is not solely a problem of non-resident taxpayers in paid employment but as well a problem of self-employed non-residents. Both groups are subject to limited tax liability if they exercise their activity in Germany and both taxpayer groups are confronted with a higher tax charge compared to resident taxpayers in a comparable situation. ${ }^{23}$

Article 48 (free movement of workers) as well as Article 52 (freedom of establishment) EC Treaty forbid to discriminate against nationals of other Member States. Consistently the scope of the above-mentioned Recommendation of the Commission has been extended to cover all non-residents regardless of the category of their professional income. The income may derive also from agricultural, forestry, industrial and commercial activities. Germany has to ensure that also this non-resident group will not be discriminated against.

e. In the Werner case ${ }^{24}$ the ECJ had held that Community law would not prevent a Member State from discriminating against its own nationals. But German Constitutional law does. It is beyond question that German Constitutional law dictates that such reverse discrimination has to be done away. If nationals of other Member States not residing in Germany are given equal treatment to that of persons who are residing in Germany German nationals residing abroad have to be treated in the same way.

\section{Conclusion}

Thousands of EU-citizens daily crossing the borders to follow their profession in the neighbouring Member State will breath a huge sigh of relief. The ruling brings them the good news that - after the physical frontiers have been swept away - from now on also an unpalatable invisible tax barrier has vanished.

It is hoped that also the Member States will appreciate the endeavours of the Court to comply their fiscal sovereignty with the fundamental freedoms guaranteed to the individuals. The Court made a most difficult tightrope walk and did not fall. The right of the Member States to write and design their income tax law has been expressively confirmed. Furthermore there has not been cast any doubt about the traditional national and international different treatment between taxpayers being subject to limited tax liability and those who are not. Nevertheless, the Member States by laying down the rules governing income tax must respect the limits set by Community law. They may not infringe the freedoms which are guaranteed to all nationals of the Member States.

\footnotetext{
${ }^{24}$ See footnote 2 .
} 